\title{
The Resource-based View and SME Internationalisation: An Emerging Economy Perspective
}

\author{
Rūta Kazlauskaitè, Erkko Autio, Modestas Gelbūda, Tadas Šarapovas
}

\begin{abstract}
A B S T R A C T
Objective: The aim of the paper is to advance the development of theory in the field of international business by seeking to understand to what extent the resource-based view (RBV), built on the experience and evidence from advanced economies, helps understand the internationalisation process of emerging economy SMEs.
\end{abstract}

Research Design \& Methods: The paper is built on a systematic literature review of peer-reviewed journal articles on SME internationalisation motives and enablers in emerging economies.

Findings: The RBV arguments explain the internationalisation process of emerging economy SMEs only to some extent. In contrast to advanced economy firms, the internationalisation of SMEs from emerging economies is more likely to be driven by the exploitation of cost advantage, and motivation to gain new knowledge that is unavailable domestically and enhance their domestic market reputation. Besides it is more handicapped by a lack of internationalisation experience or international ties.

Implications \& Recommendations: To understand the process of emerging economy SME internationalisation, it is necessary to study to what extent other logics contribute to its explication. Further research should also seek to synthesise findings of the above major theoretical frameworks in the context of emerging economy SME internationalisation process.

Contribution \& Value Added: The originality of this work lies in studying the internationalisation motives and enablers of indigenous SMEs in emerging economies and challenging the applicability of the RBV arguments in this specific context.

Article type: conceptual article

Keywords: $\quad$ resource-based view; internationalisation; emerging economy; SME JEL codes: M16, F23, L21, L26

\section{Suggested citation:}

Kazlauskaitè, R., Autio, E., Gelbūda, M., \& Šarapovas, T. (2015). The Resource-based View and SME Internationalisation: An Emerging Economy Perspective. Entrepreneurial Business and Economics Review, 3(2), 53-64. doi: 10.15678/EBER.2015.030205 


\section{INTRODUCTION}

Emerging economies are gaining growing prominence in the global economy. Collectively they account for about one third of the world's gross domestic product, and their growth rates tend to exceed those of advanced economies (Hale, 2012). Furthermore, more and more emerging economy firms are expanding their operations into international markets (Aulakh et al., 2000). The majority of those firms are, however, still in the early stages of the internationalisation process, with exports being one of the dominant foreign market entry modes, which underlines the relevance of research understanding of strategies these firms follow in their internationalisation process.

Prior research on emerging economy firm internationalisation has mainly focused on strategies of large companies, in many cases including state-owned and foreign-owned organisations (Amal \& Rocha Freitag Filho, 2009). This in turn leaves internationalisation motives and enablers of small and medium-sized (SME) enterprises, which constitute the largest part of the national economy in most emerging economy contexts, by and large an under-researched area.

One of the most commonly used theoretical frameworks in the internationalisation research is the resource-based view (RBV) (Peng, 2001). It has been recognised as one of the top three most useful theories helping to understand firm strategy in emerging economies (Hoskisson, Eden, Lau \& Wright, 2000). Put succinctly, the resource-based view explores how firms can build, access, control, and leverage firm-specific resources for sustainable competitive advantage (Barney, 1991). The more valuable, rare, and difficult to substitute and copy such resources are, the more likely they will support sustainable competitive advantage.

In the context of internationalisation, resource-based notions are echoed in the distinction between home-base exploitation and home-base extension logics of internationalisation (Kuemmerle, 2002). This framework suggests that firms can internationalise on the back of resource-based advantages that exist in their home base; or they can use internationalisation to create resource-based advantages by creating valuable and difficult-to-substitute resource combinations across national borders. Both logics have been applied to explore internationalisation processes in emerging economy contexts (Wright, Filatotchev, Hoskisson \& Peng, 2005; Cui \& Jiang, 2010). However, such studies have mainly focused on large state-owned firms.

Seen through the resource-based lens, the size of the firm can be considered an important determinant of a firm's export activities, as size proxies the magnitude of managerial and financial resources and the firm's strength in the domestic market (Singh, 2009). Echoing this stance, resource-based research on SME internationalisation from emerging economies has reported predominantly positive effects of SME size on export sales (Singh, 2009), export performance (Alvarez, 2004), export intensity (Manolova, Manev \& Gyoshev, 2010), and outward foreign direct investment (OFDI) motives and behaviours (Huang \& Renyong, 2014). However, these studies have as yet failed to produce a coherent theoretical synthesis of how resources impact internationalisation outcomes in emerging economy SMEs. We advance such a synthesis in this paper. 


\section{MATERIAL AND METHODS}

In this paper we extend the existing research understanding of the internationalisation process of emerging economy SMEs. Specifically, we explore the following research questions in our literature review:

- What are the resources that internationalising emerging economy firms leverage for internationalisation?

- What kinds of resources characterise the home base of internationalising emerging economy firms?

- What are the international resource combinations that emerging economy firms pursue through internationalisation?

In the following, we first review prior literature on the internationalisation process of indigenous emerging economy SMEs in order to identify the resources they tend to leverage for internationalisation. Next, we identify the most characteristic home base resources of those firms, as discussed in the literature. Then we identify dominant resource combinations that emerging economy SMEs pursue through internationalisation. Based on our literature review findings, we offer a number of propositions that underline the distinct features of internationalising emerging economy SMEs in comparison to firms from advanced economies. We close the paper with some conclusions and implications for further research.

As regards the review process, we first developed a preliminary list of search terms and then supplemented it based on expert opinion. The search terms used were as follows: internationalisation, international/foreign expansion, outward FDI, export, born global, joint venture, emerging market/economy, CEE, transition market/economy/ /country. Next, we determined journal quality criteria and developed a list of journals to search for papers. We limited our review to journals included in Harzing (2014) list in the fields of international business, entrepreneurship, strategy and general management.

\section{LITERATURE REVIEW AND THEORY DEVELOPMENT}

\section{Leverage of Home-Base Resources in SME Internationalisation Process}

Lacking material resources, new ventures have to compete on their resourcefulness, by doing more with less tangible resources and complementing these with intangible resources. In addition, emerging economy SMEs operate in less munificent environments in comparison to SMEs from advanced economies, which further underscores the relevance of intangible resources for them. So what are the resources that characterise the home-base of emerging economy SMEs and what resources do they leverage for internationalisation?

Prior empirical research shows that one valuable, rare and difficult-to-imitate intangible resource that emerging economy SMEs tend to leverage in their internationalisation endeavours is their existing stocks of knowledge (Kocak \& Abimbola, 2009; Prashantham \& Dhanaraj, 2010; Wach, 2014; Yamakawa, Khavul, Peng, \& Deeds, 2013). New ventures from emerging economies tend to capitalise on their international market knowledge and technological know-how. International market knowledge is valuable, as it enables firms to lower their costs in export transactions (Peng \& York, 
2001). This kind of knowledge is usually gained through the entrepreneur's international experience in the form of education and work experience abroad. Empirical findings also show that the international experience of the founder-manager is more valuable and relevant when the SME chooses to internationalise to advanced economy markets rather than other emerging economy markets (Yamakawa et al., 2013), as advanced economy markets exhibit greater institutional differences relative to other emerging economy markets.

Larger stocks of technological knowledge gained by the firm through its foundermanager's technical background and employees (proportion of employees engaged in $R \& D$ ) is another resource that is often leveraged for internationalisation by new ventures from emerging economies (Yamakawa et al., 2013; Singh, 2009; Karadeniz \& Göçer, 2007). As a case in point, patent possession was found to have contributed to rapid internationalisation of Estonian firms (Vissak, 2007). However, technological know-how was found to be more salient when seeking to enter advanced economy markets, and it was not similarly leveraged for internationalisation to other emerging economy markets (Yamakawa et al., 2013).

Human capital of the founder-manager was also found to serve as valuable resource that was leveraged for internationalisation by emerging economy SMEs. Such firms were found to have entrepreneurs with higher levels of education, for example (Alon et al., 2013; Thai \& Chong, 2008). Reflecting generic human capital, the employment size also characterised internationalising emerging economy SMEs, with larger SMEs likely to have better access to unique and inimitable combinations of human resources, knowledge and capabilities (Alon et al., 2013).

Higher stocks of social capital in the form of domestic networks (Manolova et al., 2010) and through return migration or former work experience in multinational corporations (MNCs) may also serve as a valuable and difficult-to-imitate resource for internationalisation (Prashantham \& Dhanaraj, 2010; Kocak \& Abimbola, 2009). However, some research has noted that social capital tends to decline over time and needs to be replenished. Thus, expanding the SME's stocks of social capital expansion is equally important for emerging economy SME internationalisation as is the exploitation existing stocks of social capital (Prashantham \& Dhanaraj, 2010).

Emerging economy SMEs also tend to leverage their reputation for internationalisation. Notably, domestic market reputation is a significant factor in the firm's choice between emerging and advanced economy markets. Empirical findings show that reputation established in the domestic market can be exploited and serve as an advantage when the SME seeks to internationalise to other emerging economy markets (Yamakawa et al., 2013), as it already has experience in operating in environments characterised by underdeveloped institutions and difficult governance conditions (Cuervo-Cazurra \& Genc, 2008). Domestic reputation of an emerging economy firm is less relevant for stakeholders in advanced economies, however. Thus, reputation is a resource that emerging economy SMEs seek to build rather than exploit in advanced economies.

In addition to intellectual, human, and social capital and reputation, also governance and monitoring mechanisms were identified as intangible resource that SMEs from emerging economies (China in this case) leverage for internationalisation (Luo, Zhao, 
Wang \& Xi, 2011). This resource likely helps emerging economy SMEs overcome hindrances posed by deficient institutions and governance structures in their home countries.

Among the tangible resources, internationalising SMEs from emerging economies may seek to compete on their new technology and unique offerings in terms of new products or services (Alon et al., 2013). For instance, differentiation competencies, measured by R\&D intensity and new product ratio, were found to have a positive effect on export propensity and intensity (Gao et al., 2010), while innovative products and production processes were found to be one of the main sources of positive performance in a case study of Turkish born globals (Kociak \& Abimbola, 2009). However, proprietary technology at start-up, like the above mentioned domestic reputation, is found to be more relevant when firms choose to internationalise to other emerging economy markets, as the competitive benefits of such technology are considered to be offering lesser competitive benefits in advanced economies (Yamakawa et al., 2013). Inward internationalisation advantage (i.e., tapping into resources outside the home country) was also found to have significant effect on emerging economy SMEs' internationalisation proclivity (Luo et al., 2011).

As such, the above mentioned intangible and tangible resources of emerging economy do not differ much from those discussed in the mainstream internationalisation literature. After all, firms tend to draw on the same categories of resources (e.g., financial, human, and social capital) regardless of the economy they reside in. Our literature review suggests that differences in resource deployment arise from three aspects: first, the regulating effect the firm's context has on resource deployment; second, the quality of the resources a firm can leverage; and third, the quantity of the resources the firm can build and access. We next discussed each in turn.

As seen in the above review, emerging economy contexts can moderate the effect of a given SME's resources on its internationalisation decisions. We saw that emerging economy SMEs are more likely to leverage their technology resources for internationalisation to other emerging economies, rather than advanced economies (Vissak, 2007). Similarly, SMEs that built their reputations in emerging economies are more likely to leverage their reputations for internationalisation to other emerging economies than to advanced economies (Yamakawa et al., 2013). This may be for two reasons. First, emerging economy conditions regulate the quality of the resources SMEs are able to build in their home bases. The quality of technological know-how built by emerging economy SMEs may be better suited in contexts where the technological infrastructure is similar to their home base - i.e., other emerging economies. When seeking to leverage their domestically built technological know-how in advanced economies, emerging economy SMEs may be at a disadvantage when trying to adapt their technologies to the high-quality technological infrastructure advanced economies enjoy. Similarly, the quality of reputational resources built in an emerging economy context may also be more readily leveraged in other emerging economies. We therefore propose:

Proposition 1: Intangible resources built in an emerging economy context are better suited for internationalisation to other emerging economy markets than to advanced economy markets. 
An advantage emerging economy SMEs can mostly rely on relates to their overall lower labour, production, R\&D, product development and marketing costs (Aulakh, Kotabe, \& Teegen, 2000; Nowiński \& Rialp, 2013). Firms from emerging economies like China also enjoy a cost advantage due to improvements in production capabilities driven by FDI (Guthrie, 2005), high levels of domestic competition (Child \& Rodrigues, 2005), and low-cost financing resources available due to capital market imperfections (Cui, Jiang, \& Stening, 2011). Therefore being at a disadvantage in comparison to advanced economy markets, internationalising firms from emerging economies are more likely to exploit their cost advantage and pursue a low-cost strategy when entering advanced economy markets (Aulakh, Kotabe, \& Teegen, 2000). Cost advantage, measured by production cost ratio, and selling and administrative cost ratio, was found to have a positive effect on export propensity and intensity in a sample of private Chinese manufacturing firms (Gao, Murray, Kotabe \& Lu, 2010). Empirical evidence also shows that the positive effects of the cost-based strategy on export performance are stronger among emerging economy firms that internationalise to advanced rather than other emerging economy markets where domestic firms can also draw on low-cost resources and where a differentiation strategy may therefore be more successful (Aulakh et al., 2000). A case study by Liu et al. (2008) shows that low price alone does not suffice to successfully compete in international markets, and it is the quality-price ratio that matters.

Summarising, access to low-cost resources may be seen as a distinctive emerging economy advantage for emerging economy SMEs. We therefore propose:

Proposition 2: Emerging economy SMEs are more likely to exploit domestic resource cost advantages than firms internationalising from advanced economy contexts.

In addition to resource quality, also resource quantity can matter. Emerging economy contexts are less munificent than advanced economy contexts, making it more challenging for SMEs to access and mobilise resources for internationalisation. The institutional environment that emerging economy SMEs operate in is also characterised by lack of formal and informal institutions that are necessary for efficient market-based exchanges, which makes it more difficult for emerging economy firms to access capital, labour and distribution channels (Khanna \& Palepu, 2000). They also have to cope with risks stemming from their unstable political and economic environment (Gaur, Kumar, \& Singh, 2014). Therefore to overcome their shortage of and limited access to critical resources and cope with environmental risks, emerging economy SMEs cannot rely on their stocks of resources alone and may instead seek resources through networks and business group affiliation. A stronger domestic position of an affiliated firm provides it with a stronger risk-taking ability to venture into international markets. Empirical evidence, though scarce, also supports positive effects of business group affiliation on SME internationalisation (Singh, 2009; Huang \& Renyong, 2014). A longitudinal case study of a Chilean retailer revealed that the internationalisation of an emerging market firm may be facilitated by belonging to a family conglomerate with a lengthy history of operations in the marketplace. The reputation and tradition provided by the family name support the creation of a competitive advantage and greater legitimacy over developed country companies in the eyes of other emerging-market actors (Bianchi, 2009). In contrast, firms in advanced economies operate in an institutional context with well- 
functioning markets which makes it easier for them to access the required financial, technological, and managerial resources (Khanna \& Palepu, 2000). We therefore propose:

Proposition 3: SMEs internationalising from emerging economy contexts are more likely to belong to business groups than SMEs internationalising from advanced economy contexts.

\section{Home-Resource Base Characteristics of Internationalising Emerging Economy SMEs}

As seen above, internationalising firms from emerging economies leverage their stocks of technological and market knowledge, intellectual and social capital, domestic reputation, new technology and unique product and service offerings, and labour cost advantage. However, due to deficiencies in the institutional environment of emerging economies, and the smallness of the firms themselves, not all internationalising SMEs can access critical resources required for internationalisation. Though prior research on barriers to internationalisation in emerging economy contexts is limited, it can still be concluded from existing studies that internationalising emerging economy SMEs often lack such critical resources as venture capital (Nowiński \& Rialp, 2013), international experience, human capital and managerial skills, international network ties (Liu et al., 2008; Nowiński \& Rialp, 2013; Thai \& Chong, 2008), ICT technology and skills (Thai \& Chong, 2008), and advanced technology (Liu et al., 2008). These findings should be interpreted with caution, however, and generalisations cannot be made without taking into consideration the specifics of the national institutional context and the stage the specific country is at in its transition to the market economy, as differences across emerging economies emerging economy can be pronounced. We therefore propose:

Proposition 4: SMEs internationalising from emerging economy contexts are more likely than firms internationalising from advanced economy contexts to be handicapped by lack of internationalisation experience, managerial skills and international ties required to support internationalisation.

\section{Extension of Home-Base Resources in the Internationalisation Process of Emerging Economy SMEs}

Gaining access to resources not available in the home base can be an important motive driving internationalisation (Barney, Wright \& Ketchen, 2001). Firms may choose to internationalise not only to exploit their domestic resource base, but also, to access assets and resources abroad, i.e., to remedy a domestic resource handicap.

What resources do emerging economy firms seek through internationalisation? Prior research on resource extension through internationalisation is rather modest, as most internationalisation research has focused on resource exploitation. Among the few studies that explored home-base extension, access to reputation and knowledge were identified as drivers of internationalisation from emerging economy contexts. Specifically new ventures were found to seek internationalisation in order to enhance their reputation in their domestic market (Yamakawa et al., 2013), which enabled the firms to strengthen their domestic market position. This way, internationalisation served to build a domestic advantage. Hence we propose: 
Proposition 5: New ventures from emerging economies are more likely to seek internationalisation in order to enhance their domestic market reputation than firms from advanced economies.

Emerging economy SMEs may also choose to internationalise to source new knowledge that is unavailable locally. For instance, Yamakawa et al. (2013) findings showed that firms with larger proportions of employees based abroad are more likely to choose to internationalise to advanced economy markets. Also, emerging economy SMEs that seek new knowledge through direct sales rather than intermediation are also more likely to enter advanced economy markets. A case study analysis of four Indian SMEs showed that to gain new technological knowledge and market learning, firms seek to expand their social capital, which they do by (i) extending their initial network of contacts, (ii) making proactive probes into new international ties, and (iii) leveraging networks within their domestic network to establish new international ties (Prashantham \& Dhanaraj, 2010).

\section{CONCLUSIONS}

The aim of this paper was to formulate a coherent resource-based theory that articulates the specifics of the internationalisation process of SMEs from emerging economies. To attain this aim we critically studied prior research in the field. To advance the understanding of emerging economy SME internationalisation, we specifically focused on the resource-based view, one of the dominant theoretical frameworks used in prior internationalisation literature. We used our review to build a resource-based synthesis to explain internationalisation patterns of emerging economy SMEs.

Our review concludes that emerging economy SMEs seek to leverage their intangible and tangible resources in their internationalisation. Among the former, they exploit their stocks of knowledge (international market knowledge and technological know-how), intellectual capital, social capital and reputation; while among the latter firms may seek to compete on their new technologies, unique products or services. In terms of resources used, emerging economy SMEs are not different from their advanced economy counterparts. The distinctive features of emerging economy SME internationalisation arise from: (i) the way emerging economy contexts moderate the effect of different resource categories on internationalisation decisions; (ii) the quality of resources that can be build and accessed in emerging economy contexts; and (iii) on the quantity of resources that can be mobilised in emerging economy contexts. What makes their resource base distinct from advanced economy firms are their overall lower costs (e.g., labour, production, R\&D, marketing, product development). Emerging economy firms put more emphasis on cost advantage - which inevitably is temporary, and raw materials and supplies.

Constrained by the specifics of their institutional environments (lack of formal and informal institutions) emerging economy SMEs may find it more challenging to access critical resources. Besides, they have to cope with higher environmental risks that may arise due to economic and political instability. Therefore, internationalising emerging economy SMEs are more likely to be affiliated with business groups than advanced economy firms. 
Our review also reveals that the home resource base of internationalising SMEs from emerging economies is likely to differ from that of advanced economy firms in that emerging economy SMEs are more likely to be handicapped by lack of internationalisation experience, managerial skills and international ties required to support internationalisation. To overcome such resource handicaps, emerging economy SMEs are more likely to seek to upgrade their domestic resource base in response to challenges introduced by exposure to export market competition.

Another distinct feature of emerging economy SMEs is their motivation to seek internationalisation in order to enhance their domestic market reputation. Another resource that these firms may seek through internationalisation is new knowledge that is unavailable in the domestic market. None of these characteristics have been discussed in prior internationalisation and RBV research in advanced economy contexts.

To conclude, it may be stated that though some resource-based arguments apply to emerging economy contexts, resource-based insights as developed in advanced economy contexts do not directly apply to the internationalisation process of emerging economy SMEs. To understand the process of emerging economy internationalisation, it is necessary to study to what extent other theoretical logics and internationalisation frameworks, such as the process theory of internationalisation, international entrepreneurship, network theory, and institutional theory can be applied to understand this phenomenon. Further research should seek to synthesise findings from these other theoretical frameworks in the context of emerging economy SME internationalisation process.

\section{REFERENCES}

Alon, I., Yeheskel, O., Lerner, M., \& Zhang, W. (2013). Internationalization of Chinese Entrepreneurial Firms. Thunderbird International Business Review, 55(5), 495-512. doi: 10.1002/tie.21566

Alvarez, E. (2004). Sources of export success in small-and medium-sized enterprises: the impact of public programs. International Business Review, 13(3), 383-400.

Amal, M., \& Rocha Freitag Filho, A. (2010). Internationalization of small-and medium-sized enterprises: a multi case study. European Business Review, 22(6), 608-623. doi: 10.1108/09555341011082916

Aulakh, P. S., Kotabe, M., \& Teegen, H. (2000). Export strategies and performance of firms from emerging economies: Evidence from Brazil, Chile, and Mexico. Academy of Management Journal, 43(3), 342-361.

Barney, J., Wright, M., \& Ketchen, D. J. (2001). The resource-based view of the firm: Ten years after 1991. Journal of Management, 27(6), 625-641.

Barney, J. (1991). Firm resources and sustained competitive advantage. Journal of Management, 17(1), 99-120.

Bianchi, C. (2009). Retail internationalisation from emerging markets: case study evidence from Chile. International Marketing Review, 26(2), 221-243.

Child, J., \& Rodrigues, S. B. (2005). The Internationalization of Chinese Firms: A Case for Theoretical Extension? Management and Organization Review, 1(3), 381-410. 
Cuervo-Cazurra, A., \& Genc, M. (2008). Transforming disadvantages into advantages: developingcountry MNEs in the least developed countries. Journal of international Business Studies, 39(6), 957-979.

Cui, L., Jiang, F., \& Stening, B. (2011). The entry-mode decision of Chinese outward FDI: Firm resources, industry conditions, and institutional forces. Thunderbird International Business Review, 53(4), 483-499.

Cui, L., \& Jiang, F. (2010). Behind ownership decision of Chinese outward FDI: Resources and institutions. Asia Pacific Journal of Management, 27(4), 751-774. doi: 10.1002/tie.20425

Gao, G. Y., Murray, J. Y., Kotabe, M., \& Lu, J. (2010). A "strategy tripod" perspective on export behaviors: Evidence from domestic and foreign firms based in an emerging economy. Journal of International Business Studies, 41(3), 377-396.

Guthrie, D. (2005). Organizational learning and productivity: State structure and foreign investment in the rise of the Chinese corporation. Management and Organization Review, 1(2), 165-195.

Hale, D. (2012 September). The Importance of Emerging Markets. CFA Institute Conference Proceedings Quarterly, 29(3), 43-50.

Harzing, A.W. (2014). Journal Quality List. Retrieved on March 15, 2015 from http://www.harzing.com/

Hoskisson, R. E., Eden, L., Lau, C. M., \& Wright, M. (2000). Strategy in Emerging Economies. The Academy of Management Journal, 43(3), 249-267. doi: 10.2307/1556394

Huang, X., \& Renyong, C. (2014). Chinese Private Firms' Outward Foreign Direct Investment: Does Firm Ownership and Size Matter? Thunderbird International Business Review, 56(5), 393-406. doi: 10.1002/tie.21629

Karadeniz, E. E., \& Göçer, K. (2007). Internationalization of small firms: A case study of Turkish small-and medium-sized enterprises. European Business Review, 19(5), 387-403.

Khanna, T., \& Palepu, K. (2000). Is Group Affiliation Profitable in Emerging Markets? An Analysis of Diversified Indian Business Groups. The Journal of Finance, 55(2), 867-891.

Kocak, A., \& Abimbola, T. (2009). The effects of entrepreneurial marketing on born global performance. International Marketing Review, 26(4/5), 439-452.

Kuemmerle, W. (2002). Home base and knowledge management in international new ventures. Journal of Business Venturing, 17(2), 99-122.

Liu, X., Xiao, W., \& Huang, X. (2008). Bounded entrepreneurship and internationalisation of indigenous Chinese private-owned firms. International Business Review, 17(4), 488-508.

Luo, Y., Zhao, H., Wang, Y., \& Xi, Y. (2011). Venturing Abroad by Emerging Market Enterprises. Management International Review, 51(4), 433-459. doi: 10.1007/s11575-011-0087-y

Manolova, T. S., Manev, I. M., \& Gyoshev, B. S. (2010). In good company: The role of personal and inter-firm networks for new-venture internationalization in a transition economy. Journal of World Business, 45(3), 257-265.

Naudé, W., \& Rossouw, S. (2010). Early international entrepreneurship in China: Extent and determinants. Journal of International Entrepreneurship, 8(1), 87-111.

Nowiński, W., \& Rialp, A. (2013). Drivers and strategies of international new ventures from a Central European transition economy. Journal for East European Management Studies, 18(2), 191-231.

Peng, M. W. (2001). The resource-based view and international business. Journal of Management, 27(6), 803-829. 
Peng, M. W., \& York, A. S. (2001). Behind intermediary performance in export trade: Transactions, agents, and resources. Journal of International Business Studies, 327-346.

Peng, M. W., \& Luo, Y. (2000). Managerial ties and firm performance in a transition economy: The nature of a micro-macro link. Academy of Management Journal, 43(3), 486-501.

Prashantham, S., \& Dhanaraj, C. (2010). The dynamic influence of social capital on the international growth of new ventures. Journal of Management Studies, 47(6), 967-994.

Singh, D. A. (2009). Export performance of emerging market firms. International Business Review, 18(4), 321-330. doi.org/10.1016/j.ibusrev.2009.03.002

Tang, Y. K. (2011). The Influence of networking on the internationalization of SMEs: Evidence from internationalized Chinese firms. International Small Business Journal, 29(4), 374-398.

Thai, M. T. T., \& Chong, L. C. (2008). Born-global: The case of four Vietnamese SMEs. Journal of International Entrepreneurship, 6(2), 72-100.

Vissak, T. (2007). The Emergence and Success Factors of Fast Internationalizers. Journal of EastWest Business, 13(1), 11-33.

Yamakawa, Y., Peng, M. W., \& Deeds, D. L. (2008). What drives new ventures to internationalize from emerging to developed economies? Entrepreneurship Theory and Practice, 32(1), 59-82.

Yamakawa, Y., Khavul, S., Peng, M. W., \& Deeds, D. L. (2013). Venturing from Emerging Economies. Strategic Entrepreneurship Journal, 7(3), 181-196. doi: 10.1002/sej.1158

Wach, K. (2014). The Role of Knowledge in the Internationalisation Process: An Empirical Investigation among Polish Businesses (chapter 7). In: Kiendl-Wendner, D. \& Wach, K. (Eds.), Iternational Competitiveness in Visegrad Countries: Macro and Micro Perspectives (pp. 143158). Graz: Fachhochschule Joanneum.

Wright, M., Filatotchev, I., Hoskisson, R. E., \& Peng, M. W. (2005). Strategy Research in Emerging Economies: Challenging the Conventional Wisdom. Journal of Management Studies, 42(1), 1 33. 


\section{Authors}

Contribution share of authors is equal and amounted to $25 \%$ each of them.

\section{Rūta Kazlauskaitè}

Professor in the Area of Human Resource Management, Corporate Social Responsibility and Strategy at Management Department, ISM University of Management and Economics (Lithuania). PhD in Business Administration by ISM University of Management and Economics (Lithuania).

\section{Erkko Autio}

Professor in the Area of Technology Venturing and Entrepreneurship at Innovation and Entrepreneurship Department, Imperial College London (the United Kingdom) and Professor at ISM University of Management and Economics (Lithuania). PhD by Helsinki University of Technology (Finland).

\section{Modestas Gelbūda}

Associate Professor in the Area of Strategy, Entrepreneurship and Innovation at Management Department, ISM University of Management and Economics (Lithuania). PhD in Business Administration by Aalborg University (Denmark).

\section{Tadas Šarapovas}

Associate Professor in the Area of Economics and Strategy at Economics and Politics Department, ISM University of Management and Economics (Lithuania). PhD in Economics by Kaunas University of Technology (Lithuania).

\section{Correspondence to:}

Assoc. Prof. Modestas Gelbūda, PhD

ISM University of Management and Economics

Arkliu Street 18

01305 Vilnius, Lithuania

modestas.gelbuda@ism.It

\section{Acknowledgements and Financial Disclosure}

This research has been funded by the European Social Fund under the Global Grant measure (Project No. VP1-3.1-SMM-07-K-03-074).

\section{Copyright and License}

This article is published under the terms of the Creative Commons Attribution - NonCommercial - NoDerivs (CC BY-NC-ND 3.0) License http://creativecommons.org/licenses/by-nc-nd/3.0/ 